\title{
Effect of ammonia treatment conditions of wheat straw on organic matter degradation measured in situ and by the gas test method
}

\author{
Rabéha CHABACA ${ }^{\mathrm{a}}$, Saddek TrIKI ${ }^{\mathrm{a}}$, Aristide LARWENCE ${ }^{\mathrm{b}}$, \\ Michel PAYNOT ${ }^{c}$, Jean-Louis TISSERAND ${ }^{d}$
}

a INA, Département de Zootechnie,16200 El-Harrach, Algeria

${ }^{\mathrm{b}}$ ENSIA-SIARC, BP 5098, 34033 Montpellier Cedex, France

${ }^{\mathrm{c}}$ INRA, BP 1540, 21034 Dijon Cedex, France

d ENESAD, BP 1607, 21036 Dijon Cedex, France

(Received 30 November 2000; accepted 28 May 2002)

\begin{abstract}
Organic matter degradation (OMD) was studied with the techniques of in situ degradation and in vitro gas production (gas test) on 16 straws (TS) treated under different conditions of ammonia concentration ( 3 and $5 \%$ ), duration (15, 30, 45 and 75 days) and temperature $\left(15\right.$ and $\left.35^{\circ} \mathrm{C}\right)$. Gas production (GP) and OMD were measured at 2, 4, 8, 16, 24 and $48 \mathrm{~h}$. The results showed that after treatment, compared with the untreated straw (US), the OMD at $48 \mathrm{~h}$, GP at $48 \mathrm{~h}$ and organic matter theoretical digestibility (OMTD) increased by 31,25 and $19 \%(P<0.01)$. Among the treatment factors, temperature was mainly involved in the increase in OMD, GP and OMTD. The correlations established between OMD and GP at every kinetic point, and between OMTD and GP at every kinetic point were low. They were high only during the first $24 \mathrm{~h}$ of the GP incubation, particularly between OMTD and GP at $8 \mathrm{~h}$. This does not allow the utilisation of the GP method to predict the OMD in situ, but GP at $8 \mathrm{~h}$ can be used for a rapid classification of the straws.
\end{abstract}

\section{gas production / degradability / ammonia treated straws}

Résumé - Effet des conditions de traitement de la paille de blé à l'ammoniac sur la dégradation de la matière organique mesurée in situ et par la méthode du gaz-test. La dégradation de la matière organique (DMO) de 16 pailles traitées en laboratoire, obtenues selon différentes doses d'ammoniac ( 3 et $5 \%$ ), de durées $(15,30,45$ et 75 jours $)$ et de température de traitement $\left(15\right.$ et $\left.35^{\circ} \mathrm{C}\right)$ a été mesurée par la méthode in sacco et celle du gaz-test. La production de gaz (PG) et la DMO ont été mesurées à $2,4,8,16,24$ et 48 h d'incubation. Après traitement, la DMO, la PG à 48 h et la DTMO (dégradabilité théorique de la MO), ont augmenté respectivement de 31, 25, et $19 \%$. La température

\footnotetext{
* Correspondence and reprints

Fax: 33 (0)4 676170 55; e-mail: larwence@siarc.cnearc.fr
} 
est le facteur essentiel de cette amélioration. Les corrélations entre la cinétique de DMO et celle de la PG d'une part et la cinétique de la PG et de la DTMO d'autre part sont faibles. Elles sont significatives jusqu'au point $24 \mathrm{~h}$ d'incubation. Des corrélations élevées $(\mathrm{r}=0,83)$ sont obtenues entre DMO et PG à $8 \mathrm{~h}$. Ce résultat peut être retenu pour réaliser un classement rapide entre pailles.

production de gaz / dégradabilité / pailles traitées à l'ammoniac

\section{INTRODUCTION}

Ammonia treatment of straws increases their digestibility (47 to $64 \%, \mathrm{n}=18$ ) and their intake in sheep (36 to $64 \mathrm{~g} \mathrm{DM}$ per $\mathrm{kg}$ metabolic weight, $n=18$ ) [5]. Direct measurement of the in vivo digestibility is long and expensive. So, more rapid evaluation methods are often used. Among these techniques, the in situ nylon bag method is used by many scientists as a reference technique for forage evaluation [15]. The in vitro gas production technique (gas test) [11] allows routine work by performing several repetitions [2]. Moreover this technique could be more appropriate for forages containing phenolic compounds such as ammoniatreated straws $[7,8]$.

In this work we studied the kinetics of microbial organic matter degradation of sixteen ammonia-treated straws, both by in situ and gas test methods. The relationships between these two methods were analysed.

\section{MATERIALS AND METHODS}

\subsection{Straws}

A hard wheat (Triticum durum) straw harvested in Algeria was chopped then spread in $162-\mathrm{kg}$ groups and treated with ammonia before preservation in sealed plastic bags, according to different combinations of temperature $\left(15\right.$ and $\left.35^{\circ} \mathrm{C}\right)$, ammonia concentration ( 3 and $5 \%$ ) and treatment duration (15, 30, 45 and 75 days). Treatment combinations were numbered from 1 to 16 (Tab. I). During the winter,
" $15{ }^{\circ} \mathrm{C}$ bags" were kept in a room where the temperature was between 12 and $17^{\circ} \mathrm{C}$; " $35^{\circ} \mathrm{C}$ bags" were maintained at this temperature in a steam-room. At the end of each treatment, straw was aerated at ambient temperature then ground through a $0.8 \mathrm{~mm}$ grid.

\subsection{Animals}

Three Friesian cows, dry and fitted with ruminal cannula, were used. They received a 70:30 mixture of lucerne-cocksfoot hay and concentrate (43\% barley, $40 \%$ beet pulp, $10 \%$ soybean meal, 5.5\% molasses, $0.5 \%$ sodium chloride and $1 \%$ mineral and vitamin premix) twice a day ( 8 and $16 \mathrm{~h}$ ). Total diet contained $13.2 \%$ crude protein.

\subsection{Analytical methods}

Dry matter, organic matter, and crude protein were determined on untreated straw (US) and treated straws (TS1 to TS16) according to AOAC methods [1] and cell walls (NDF) were determined according to the Van Soest methods [18].

Organic matter degradation was measured in nylon bags (Blutex T50 tissue, $46 \mu \mathrm{m}$ mesh). Bag size and sample weight were those recommended by MichaletDoreau et al. [13]. Six bags were incubated at each of 6 incubation times: 2, 4, 8, 12, 24, 48 hours. After being removed from the rumen, the bags were rinsed with tap water then frozen. After defrosting they were washed with a machine $(3 \times 5 \mathrm{~min})$, kept at $30^{\circ} \mathrm{C}$ for 8 hours, then lyophilised for 24 hours, then weighed. 
Table I. Treatment identification and characteristics, and chemical composition of straws ( $\%$ dry matter).

\begin{tabular}{lccccc}
\hline Straws & Treatment & DM $(\%)$ & OM & CP & NDF \\
\hline US & - & 91.7 & 94.7 & 2.1 & 78.9 \\
TS1 & T1-C1-D1 & 92.3 & 93.4 & 9.1 & 79.1 \\
TS2 & T1-C1-D2 & 92.8 & 93.4 & 8.6 & 79.6 \\
TS3 & T1-C1-D3 & 92.9 & 94.0 & 8.7 & 80.8 \\
TS4 & T1-C1-D4 & 92.0 & 93.7 & 8.6 & 79.1 \\
TS5 & T1-C2-D1 & 90.8 & 93.7 & 8.3 & 79.6 \\
TS6 & T1-C2-D2 & 89.9 & 93.8 & 9.6 & 80.2 \\
TS7 & T1-C2-D3 & 90.3 & 94.0 & 9.1 & 78.1 \\
TS8 & T1-C2-D4 & 89.9 & 93.7 & 10.7 & 78.5 \\
TS9 & T2-C1-D1 & 90.9 & 94.4 & 11.1 & 75.6 \\
TS10 & T2-C1-D2 & 91.3 & 93.2 & 11.4 & 75.1 \\
TS11 & T2-C1-D3 & 91.6 & 94.5 & 11.7 & 75.9 \\
TS12 & T2-C1-D4 & 90.4 & 92.8 & 11.8 & 75.3 \\
TS13 & T2-C2-D1 & 90.5 & 94.3 & 13.7 & 75.5 \\
TS14 & T2-C2-D2 & 90.8 & 94.1 & 13.4 & 74.6 \\
TS15 & T2-C2-D3 & 90.4 & 93.2 & 13.1 & 74.0 \\
TS16 & T2-C2-D4 & 91.8 & 94.2 & 12.4 & 75.2 \\
\hline T1 & & & &
\end{tabular}

$\mathrm{T} 1$ and $\mathrm{T} 2$ : temperatures 15 and $35^{\circ} \mathrm{C} ; \mathrm{C} 1$ and $\mathrm{C} 2$ : ammonia concentrations 3 and 5\%; D1, D2, D3 and D4: treatment duration $15,30,45$ and 75 days.

For in vitro gas production measurement, rumen liquid was sampled on animals before feeding then 1 vol rumen liquid was mixed with 2 vol buffer solution [10] according to Menke and Steingass [12]. Samples of each straw weighing $200 \pm 5 \mathrm{mg}$, ground through a $0.8 \mathrm{~mm}$ grid, were put into two glass graduated $100-\mathrm{mL}$ syringes. After injection of $30 \pm 1 \mathrm{~mL}$ of rumen liquid-buffer mixture, the syringes were incubated at $39^{\circ} \mathrm{C}$. The syringes were then slowly shaken for 30 min per hour during the first ten hours of incubation, then after each registry. Gas volume was recorded after 2, 4, 8, 16, 24 and $48 \mathrm{~h}$ of incubation. The results were corrected using a control syringe containing rumen juice and buffer.

\subsection{Calculations and statistical analysis}

Organic matter degradation (OMD) and gas production (GP) kinetics were performed according to the model: $\mathrm{Y}=\mathrm{a}+\mathrm{b}$ $\left(1-\mathrm{e}^{-\mathrm{ct}}\right)$ [14], where a is the proportion of rapidly degraded organic matter (\%) or produced gas ( $\left.\mathrm{mL} \cdot 200 \mathrm{mg}^{-1} \mathrm{DM}\right), \mathrm{b}$ is the proportion of slowly degraded organic matter (\%) or produced gas $\left(\mathrm{mL} \cdot 200 \mathrm{mg}^{-1} \mathrm{DM}\right)$, $\mathrm{a}+\mathrm{b}$ being considered as the degradation capacity, and $\mathrm{c}\left(\mathrm{h}^{-1}\right)$ is the constant rate of degradation of $b$. Organic matter theoretical degradability was calculated as: OMTD = $\mathrm{a}+\mathrm{b} \times \mathrm{c} /(\mathrm{c}+\mathrm{k})$, where $\mathrm{k}$ is the rumen outflow rate of particles, taken as $0.06 \mathrm{~h}^{-1}$. 
An analysis of variance was performed according to the model:

$\mathrm{Y}_{\mathrm{ijkl}}=\mu+\mathrm{T}_{\mathrm{i}}+\mathrm{C}_{\mathrm{j}}+\mathrm{D}_{\mathrm{k}}+\mathrm{T} \times \mathrm{C}_{\mathrm{ij}}+\mathrm{T} \times \mathrm{D}_{\mathrm{ik}}+$ $\mathrm{C} \times \mathrm{D}_{\mathrm{jk}}+\mathrm{e}_{\mathrm{ijk} \text { l }}$, where T, C and D are the effects of temperature, ammonia concentration and treatment duration, respectively. Correlations between variables were calculated by linear regression. All calculations were made with S-PLUS software [17].

\section{RESULTS}

Residual standard deviation and determination coefficients showed an excellent adjustment of data to the model, with the exception of parameters a for OMD and $(\mathrm{a}+\mathrm{b})$ for GP (Tabs. I, II, III).

\subsection{Chemical composition}

Ammonia treatment logically increased straw crude protein content from 2.1 (US) to $13.7 \%$ (TS13); NDF content was similar between US and straw treated at $15^{\circ} \mathrm{C}$ (78.8 vs. $79.4 \%)$. Straw NDF significantly decreased $(P<0.01)$ when they were treated at $35^{\circ} \mathrm{C}(75.1 \%$ vs. 79.4$)$ (Tab. I).

\subsection{In situ organic matter degradation}

Organic matter degradation kinetics of untreated and treated straws are given in Table II. After $48 \mathrm{~h}$ of incubation, OMD was at mean $75 \%$ for treated straws (from $64 \%$ for TS2 to $83 \%$ for TS12) and $57 \%$ for US. At 16 and $24 \mathrm{~h}$ of incubation, the degradation of the treated straws represented on average 62 and $78 \%$ of the amount degraded at $48 \mathrm{~h}$. These values were similar to those observed for US (68 and 78\%, respectively).

Straw treatment increased OMTD (50 vs. $42 \%$ ); OMTD varied from 43 (TS1) to $59 \%$ (TS12). Figure 1 shows variations in OMD for US and straws treated at 15 and $35^{\circ} \mathrm{C}$. The treatment did not significantly modify the fraction, but $(\mathrm{a}+\mathrm{b})$ and $\mathrm{c}$ increased by 33 and $29 \%$, respectively $(P<0.01)$. Variations

Table II. Effect of treatment conditions on OM degradation kinetics and parameters, and on OMTD.

\begin{tabular}{|c|c|c|c|c|c|c|c|c|c|c|c|}
\hline & \multicolumn{3}{|c|}{ Treatment } & \multirow[b]{2}{*}{$\mathrm{T}$} & \multicolumn{7}{|c|}{ Main effects and interactions } \\
\hline & US & $\mathrm{TS} 15^{\circ}$ & $\mathrm{TS} 35^{\circ}$ & & $\mathrm{C}$ & $\mathrm{D}$ & $\mathrm{T} \times \mathrm{C}$ & $\mathrm{T} \times \mathrm{D}$ & $\mathrm{C} \times \mathrm{D}$ & RSD & $\mathrm{R}^{2}$ \\
\hline \multicolumn{12}{|l|}{ OMD } \\
\hline $2 \mathrm{~h}(\%)$ & 25.0 & 23.2 & 29.0 & $* *$ & NS & NS & NS & NS & NS & 1.74 & 0.95 \\
\hline $4 \mathrm{~h}(\%)$ & 26.8 & 24.3 & 9.9 & $* *$ & NS & NS & NS & NS & NS & 2.23 & 0.91 \\
\hline $8 \mathrm{~h}(\%)$ & 32.2 & 30.0 & 35.9 & $* *$ & NS & NS & NS & NS & NS & 3.22 & 0.87 \\
\hline $16 \mathrm{~h}(\%)$ & 39.2 & 41.9 & 51.4 & $* *$ & NS & NS & NS & NS & NS & 1.33 & 0.99 \\
\hline $24 \mathrm{~h}(\%)$ & 45.0 & 54.0 & 62.6 & $* *$ & NS & NS & NS & NS & NS & 2.97 & 0.95 \\
\hline 48 h (\%) & 57.4 & 73.4 & 76.6 & NS & NS & NS & NS & NS & NS & 4.00 & 0.86 \\
\hline a (\%) & 22.1 & 17.4 & 21.7 & NS & NS & NS & NS & NS & NS & 1.69 & 0.76 \\
\hline$a+b(\%)$ & 69.7 & 95.5 & 89.0 & $* *$ & NS & NS & NS & NS & NS & 1.94 & 0.97 \\
\hline $\mathrm{c}\left(\mathrm{h}^{-1}\right)$ & 0.02 & 0.02 & 0.03 & $* *$ & NS & NS & NS & NS & NS & 0.005 & 0.91 \\
\hline OMTD (\%) & 42.1 & 47.5 & 53.6 & $* *$ & $* *$ & NS & $* *$ & NS & NS & 0.93 & 0.99 \\
\hline
\end{tabular}

NS: non significant; $* *: P<0.01$; RSD: residual standard deviation; $\mathrm{R}^{2}$ : coefficient of determination. 


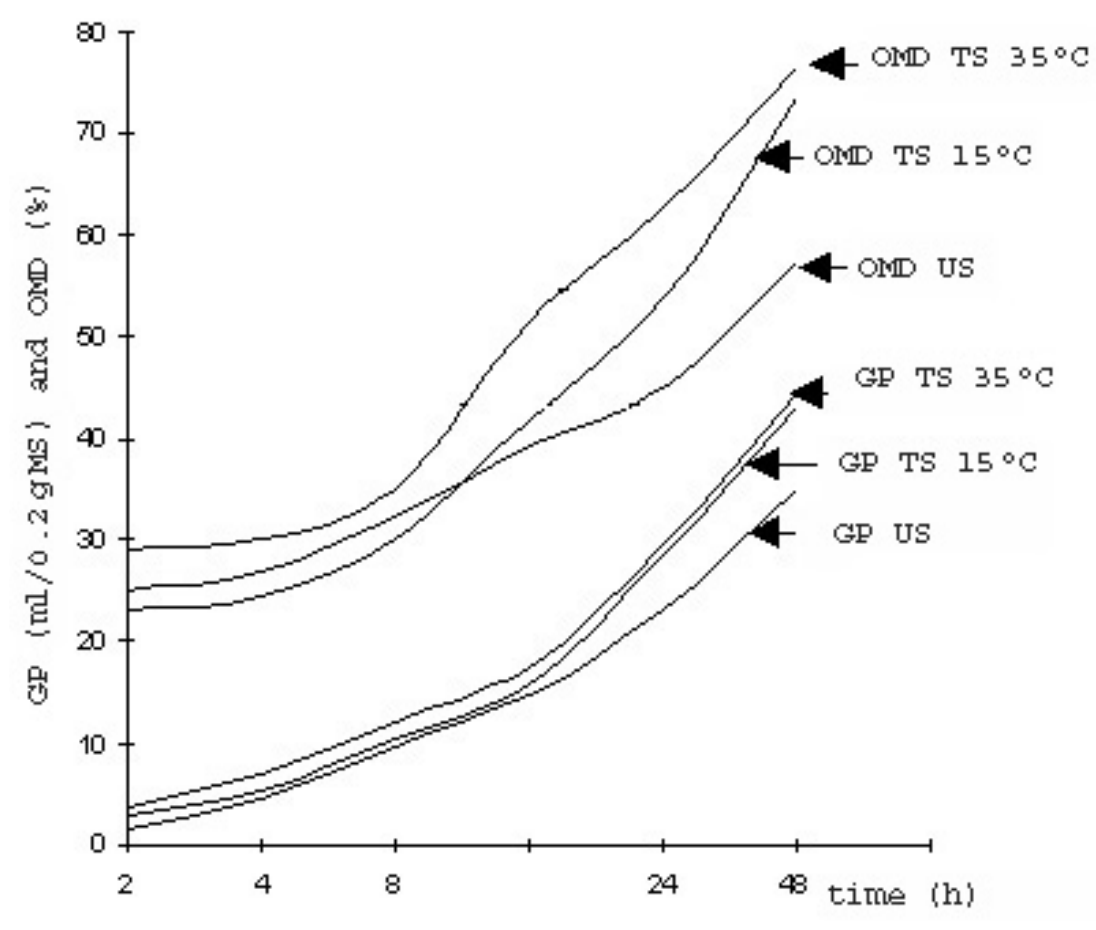

Figure 1. Effect of treatment temperature on organic matter degradation (OMD) and gas production (GP). OMD: organic matter degradation; GP: gas production; US: untreated straw; TS: treated straws at 15 or $35^{\circ} \mathrm{C}$.

in OMD, OMTD and their parameters are mainly explained by treatment temperature (Tab. II) which increased OMD significantly until $24 \mathrm{~h}$ of incubation, OMTD and c. The combined increase in ammonia concentration and temperature enhanced OMTD by $8 \%(P<0.01)$. On the contrary, the $\mathrm{b}$ fraction and thereafter $(\mathrm{a}+\mathrm{b})$ were decreased by 16 and 7\%, respectively. Although varying between 15 and 75 days, treatment duration did not modify OMD.

\subsection{In vitro gas production}

Treatment increased 48-h gas production by $25 \%$ (Tab. III). Among treated straws, gas production variations were low: from 41 to $46 \mathrm{~mL} \cdot 0.2 \mathrm{~g}^{-1} \mathrm{DM}$ for PT1 and PT15, respectively. These variations were of lower extent than those observed for OMD (Fig. 1). As for OMD and OMTD, treatment highly increased parameter $\mathrm{c}$ $(+53 \%)$ and fraction $\mathrm{a}+\mathrm{b}(+40 \%)$. The negative value of fraction a showed the occurrence of a lag time before the beginning of the fermentation, which was not observed for OMD.

Temperature and ammoniac concentration increased gas production $(P<0.001)$ between 2 and $16 \mathrm{~h}$ and between 8 and $48 \mathrm{~h}$, respectively. Temperature increased a but did not modify $\mathrm{a}+\mathrm{b}$ and $\mathrm{c}$. Moreover, $8 \mathrm{~h}$ gas production was particularly sensitive to the studied factors: it showed a positive 
Table III. Effect of treatment conditions on kinetics (in $\mathrm{mL} \cdot 0.2 \mathrm{~g}^{-1} \mathrm{DM}$ ) and parameters of in vitro gas production (GP).

\begin{tabular}{|c|c|c|c|c|c|c|c|c|c|c|c|}
\hline & \multicolumn{3}{|c|}{ Treatment } & \multirow[b]{2}{*}{$\mathrm{T}$} & \multicolumn{7}{|c|}{ Main effects and interactions } \\
\hline & US & $\mathrm{TS} 15^{\circ}$ & $\mathrm{TS} 35^{\circ}$ & & $\mathrm{C}$ & $\mathrm{D}$ & $\mathrm{T} \times \mathrm{C}$ & $\mathrm{T} \times \mathrm{D}$ & $\mathrm{C} \times \mathrm{D}$ & RSD & $\mathrm{R}^{2}$ \\
\hline GP & & & & & & & & & & & \\
\hline $2 \mathrm{~h}$ & 1.4 & 2.8 & 3.7 & $* *$ & NS & $*$ & NS & NS & $*$ & 0.23 & 0.98 \\
\hline $4 \mathrm{~h}$ & 4.5 & 5.2 & 6.9 & $* *$ & NS & NS & NS & NS & NS & 0.46 & 0.96 \\
\hline $8 \mathrm{~h}$ & 9.7 & 10.3 & 12.2 & $* *$ & $* *$ & $*$ & $* *$ & $* *$ & NS & 0.20 & 0.99 \\
\hline $16 \mathrm{~h}$ & 14.8 & 15.7 & 17.4 & $* *$ & $*$ & NS & NS & NS & NS & 0.69 & 0.95 \\
\hline $24 \mathrm{~h}$ & 23.1 & 28.4 & 29.5 & NS & $*$ & NS & NS & NS & NS & 0.90 & 0.93 \\
\hline $48 \mathrm{~h}$ & 35.0 & 43.1 & 44.5 & NS & $*$ & NS & NS & NS & NS & 1.25 & 0.91 \\
\hline $\mathrm{a}$ & -0.57 & -0.21 & 1.10 & $* *$ & NS & NS & $*$ & NS & $* *$ & 0.18 & 0.99 \\
\hline$a+b$ & 56.9 & 80.9 & 78.5 & NS & NS & NS & NS & NS & NS & 7.40 & 0.76 \\
\hline $\mathrm{c}$ & 0.012 & 0.018 & 0.019 & NS & NS & NS & NS & NS & NS & 0.001 & 0.93 \\
\hline
\end{tabular}

NS: non significant; $* P<0.05 ; * *: P<0.01 ; \mathrm{RSD}$ : residual standard deviation; $\mathrm{R}^{2}$ : coefficient of determination.

effect of both treatment, temperature and ammonia concentration, and of temperatureconcentration and temperature-duration interactions (Tab. III).

\subsection{Relationship between OMD, GP and their parameters}

Organic matter digestibility and GP varied in the same way for the first hours of incubation (Tab. IV). The highest correlation was observed between 8-h GP on the one hand and OMD at different incubation times and OMTD on the other hand. The correlations between parameters $\mathrm{a}, \mathrm{a}+\mathrm{b}$ and $\mathrm{c}$ of OMD and GP were not significant. Figure 2 shows the variations between the straws. The position of TS8 on the figure shows that a high ammonia concentration and a long treatment duration compensate for a low treatment temperature.

\section{DISCUSSION}

Among the factors studied, temperature was the most involved in variations of
OMD and GP. This result, often observed for OMD [9], can be explained by the effect of temperature on $\mathrm{CP}$ increase and cell wall decrease. However this action of temperature was more important for OMD and related parameters than for GP, for which neither parameter c nor GP at 24 or $48 \mathrm{~h}$ were modified.

When treatment temperature varied between 15 and $35^{\circ} \mathrm{C}$, GP and OMD variations were low and of the same extent for the two methods until $8 \mathrm{~h}$ incubation. Then OM degradation rate increased whereas GP degradation rate was not modified. Gas production explains 27, 37, 59 and $47 \%$ of OMD variations after $2,4,8$ and 16 h of incubation, respectively.

The correlation between OMD and PG can be limited by several factors. Dry matter which is soluble in situ is considered wrongly as fermented matter and does not correspond to gas production arising from microbial activity [2] so that OMD is overestimated [16]. Moreover, the toxic effects of phenolic compounds present in treated straws, specially p-coumaric and ferulic 


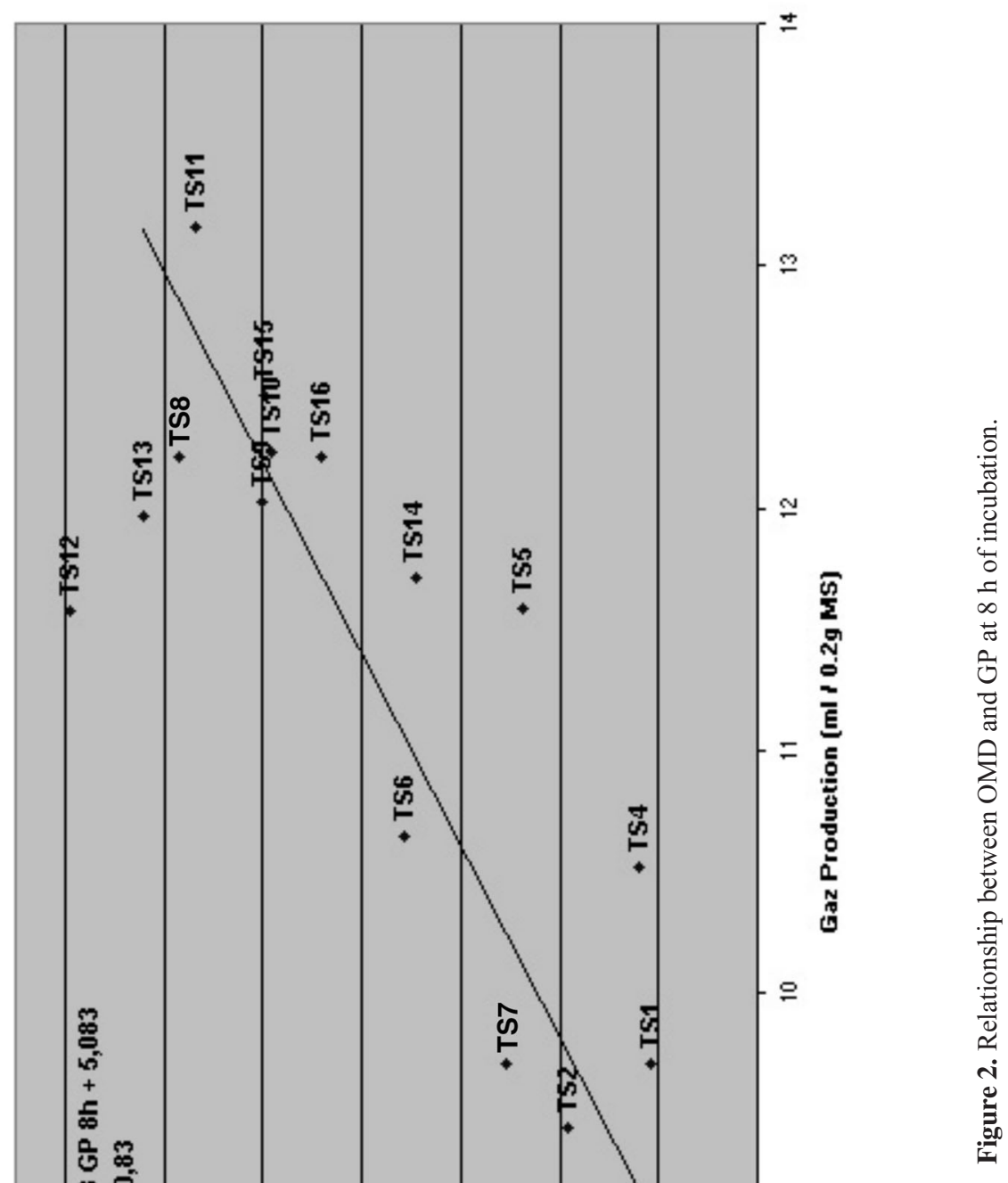


Table IV. Correlations between in situ OM degradation and in vitro gas production, and their parameters.

\begin{tabular}{|c|c|c|c|c|c|c|c|c|c|c|}
\hline & $\begin{array}{c}2 \mathrm{~h} \\
\text { in situ } \\
\text { OMD }\end{array}$ & $\begin{array}{c}4 \mathrm{~h} \\
\text { in situ } \\
\text { OMD }\end{array}$ & $\begin{array}{c}8 \mathrm{~h} \\
\text { in situ } \\
\text { OMD }\end{array}$ & $\begin{array}{l}16 \mathrm{~h} \\
\text { in situ } \\
\text { OMD }\end{array}$ & $\begin{array}{l}24 \mathrm{~h} \\
\text { in situ } \\
\text { OMD }\end{array}$ & $\begin{array}{l}48 \mathrm{~h} \\
\text { in situ } \\
\text { OMD }\end{array}$ & $\begin{array}{c}\mathrm{a} \\
\text { in situ } \\
\text { OMD }\end{array}$ & $\begin{array}{c}\mathrm{a}+\mathrm{b} \\
\text { in situ } \\
\text { OMD }\end{array}$ & $\begin{array}{c}c \\
\text { in situ } \\
\text { OMD }\end{array}$ & $\begin{array}{l}\text { TD } \\
\text { in situ } \\
\text { OMD }\end{array}$ \\
\hline $2 \mathrm{~h} \mathrm{GP}$ & $\begin{array}{c}0.53 \\
* *\end{array}$ & $\begin{array}{c}0.54 \\
* *\end{array}$ & $\begin{array}{c}0.55 \\
* *\end{array}$ & $\begin{array}{c}0.45 \\
\text { NS }\end{array}$ & $\begin{array}{c}0.69 \\
* *\end{array}$ & $\begin{array}{c}0.46 \\
\text { NS }\end{array}$ & - & - & - & $\begin{array}{c}0.60 \\
* *\end{array}$ \\
\hline $4 \mathrm{~h} \mathrm{GP}$ & $\begin{array}{c}0.58 \\
* *\end{array}$ & $\begin{array}{c}0.60 \\
* *\end{array}$ & $\begin{array}{c}0.65 \\
* *\end{array}$ & $\begin{array}{c}0.62 \\
* *\end{array}$ & $\begin{array}{c}0.64 \\
* *\end{array}$ & $\begin{array}{c}0.34 \\
\text { NS }\end{array}$ & - & - & - & $\begin{array}{c}0.61 \\
* *\end{array}$ \\
\hline $8 \mathrm{~h} \mathrm{GP}$ & $\begin{array}{c}0.76 \\
* *\end{array}$ & $\begin{array}{c}0.77 \\
* *\end{array}$ & $\begin{array}{c}0.83 \\
* *\end{array}$ & $\begin{array}{c}0.70 \\
* *\end{array}$ & $\begin{array}{c}0.73 \\
* *\end{array}$ & $\begin{array}{l}0.32 \\
\text { NS }\end{array}$ & - & - & - & $\begin{array}{c}0.76 \\
* *\end{array}$ \\
\hline 16 h GP & $\begin{array}{c}0.67 \\
* *\end{array}$ & $\begin{array}{c}0.68 \\
* *\end{array}$ & $\begin{array}{c}0.73 \\
* *\end{array}$ & $\begin{array}{c}0.67 \\
* *\end{array}$ & $\begin{array}{c}0.70 \\
* *\end{array}$ & $\begin{array}{c}0.28 \\
\text { NS }\end{array}$ & - & - & - & $\begin{array}{c}0.68 \\
* *\end{array}$ \\
\hline 24 h GP & $\begin{array}{c}0.48 \\
\text { NS }\end{array}$ & $\begin{array}{c}0.48 \\
\text { NS }\end{array}$ & $\begin{array}{c}0.54 \\
* *\end{array}$ & $\begin{array}{c}0.31 \\
\text { NS }\end{array}$ & $\begin{array}{c}0.54 \\
* *\end{array}$ & $\begin{array}{c}0.28 \\
\text { NS }\end{array}$ & - & - & - & $\begin{array}{c}0.51 \\
* *\end{array}$ \\
\hline $48 \mathrm{~h}$ GP & $\begin{array}{l}0.23 \\
\text { NS }\end{array}$ & $\begin{array}{l}0.23 \\
\text { NS }\end{array}$ & $\begin{array}{c}0.38 \\
\text { NS }\end{array}$ & $\begin{array}{l}0.06 \\
\text { NS }\end{array}$ & $\begin{array}{c}0.42 \\
\text { NS }\end{array}$ & $\begin{array}{l}0.30 \\
\text { NS }\end{array}$ & - & - & - & $\begin{array}{l}0.34 \\
\text { NS }\end{array}$ \\
\hline $\begin{array}{c}\text { a } \\
\text { in vitro } \\
\text { GP }\end{array}$ & - & - & - & - & - & - & $\begin{array}{c}0.43 \\
\text { NS }\end{array}$ & - & - & - \\
\hline $\begin{array}{c}\mathrm{a}+\mathrm{b} \\
\text { in vitro } \\
\text { GP }\end{array}$ & - & - & - & - & - & - & - & $\begin{array}{c}0.16 \\
\text { NS }\end{array}$ & - & - \\
\hline $\begin{array}{c}\mathrm{c} \\
\text { in vitro } \\
\text { GP }\end{array}$ & - & - & - & - & - & - & - & - & $\begin{array}{l}0.25 \\
\text { NS }\end{array}$ & - \\
\hline
\end{tabular}

NS: non significant; ** $P<0.01$.

acids [4] are more marked in vitro than in situ [15].

For the GP method, when incubation time is higher than $24 \mathrm{~h}$, microbial biomass decreases due either to a lack of nutritive matter, or to an accumulation of toxic compounds resulting from microbial metabolism $[2,3]$. In this experiment this should be effective after $8 \mathrm{~h}$ of incubation. This constitutes a significant bias.

Another bias could lead to another estimation of degradation measurement by the gas test technique, for example partial fermentation of dead microbes which results in gas production [6], or gas production from the buffer and from the inoculum.

\section{CONCLUSION}

The main factor increasing OMD and GP is treatment temperature. The correlation between OMD and GP for the first 24 hours of incubation was significant but only 8 -h incubations resulted in a strong relationship $(\mathrm{r}=0.83)$ and can be used for a rapid classification of straw nutritive value in ruminant feeding.

\section{REFERENCES}

[1] AOAC, Official methods of analysis, 12th ed., Washington, DC, 1975. 
[2] Blümmel M., Ørskov E.R., Comparison of in vitro gas production and nylon bag degradability of roughages in predicting feed intake in cattle, Anim. Feed Sci. Technol. 40 (1993) 109-119.

[3] Blümmel M., Steingass H., Becker K., The relationship between in vitro gas production, in vitro microbial biomass yield and ${ }^{15} \mathrm{~N}$ incorporation and its implications for the prediction of voluntary feed intake of roughages, Brit. J. Nutr. 77 (1997) 911-921.

[4] Chabaca R., Larwence A., Paynot M., Tisserand J.L., Effet de diverses conditions de traitement à l'ammoniac d'une paille de blé sur les teneurs en acides p-coumarique et férulique et sur la dégradabilité de l'azote mesurée in situ, Ann. Zootech. 49 (2000) 29-38.

[5] Chenost M., Dulphy J.P., Amélioration de la valeur alimentaire (composition, digestibilité, ingestibilité des mauvais foins et des pailles par les différents types de traitement), in: Demarquilly C. (Ed.), Les fourrages secs : récolte, traitement et utilisation, INRA Paris, 1987, pp. 199-230.

[6] Cone J.W., Van Gelber A.H., Driehuis F., Description of gas production profiles with a threephasic model, Anim. Feed Sci. Technol. 66 (1997) 31-45.

[7] Khazaal K., Markantonatos X., Nastis A., Ørskov E.R., Changes with maturity in fibre composition and levels of extractable polyphenols in greek browse: effects on in vitro gas production and in sacco dry matter degradation, J. Sci. Food Agric. 63 (1993) 237-244.

[8] Khazaal K., Boza J., Ørskov E.R., Assessment of phenolics related antinutritive effects in mediterranean browse: A comparison between the use of the in vitro gas production technique with or without insoluble polyvinylpyrolidone or nylon bag, Anim. Feed Sci. Technol. 49 (1994) 133-149.

[9] Gomez Cabrera A., Guzman J.L., Garrido A., Guerrero J.E., Traitement des pailles à l'ammoniac en zones chaudes, Opt. Méd. Sér. B, Études et recherches 6 (1994) 119-123.

[10] Lowe S.E., Theodorou M.K., Trinci A.P.J., Hespell R.B., Growth of anaerobic rumen fungi on defined and semi-defined media lacking rumen fluid, J. Gen. Microbiol. 131 (1985) 2225-2229.

[11] Menke K.H., Raab L., Salewski A., Steingass H., Fritz D., Schneider W., The estimation of the digestibility and metabolisable energy content of ruminant feedingstuffs from the gas production when they are incubated with rumen liquor in vitro, J. Agric. Sci. (Camb.) 93 (1979) 217-222.

[12] Menke K.H., Steingass H., Estimation of the energetic feed value obtained from chemical analysis and in vitro gas production using rumen fluid, Anim. Res. Dev. 28 (1988) 7-12.

[13] Michalet-Doreau B., Vérité R., Chapoutot R., Méthodologie de mesure de la dégradabilité in sacco de l'azote des aliments dans le rumen, Bull. Tech. CRZV Theix INRA 69 (1987) 5-7.

[14] Ørskov E.R., McDonald I., The estimation of protein degradability in the rumen from incubation measurements weighted according to rate of passage, J. Agric. Sci. (Camb.) 92 (1979) 499-503.

[15] Ørskov E.R., Reid G.W., Kay M., Prediction of intake by cattle from degradation characteristics of roughages, Anim. Prod. 46 (1988) 29-34.

[16] Pearce G.R., Lee J.A., Simpson R.G., Doyle P.T., Source of variation in the nutritive value of wheat and rice straw, in: Reed J.D., Capper B.S., Neat J.H. (Eds.), Proceedings of a workshop on plant breeding and the nutritive value of the crop residues, ILCA, Addis Ababa, Ethiopia, 1987, pp. 195-221.

[17] S-PLUS STATISTICS, 4-5e ed., Tokyo, 1998.

[18] Van Soest P.J., Use of detergents in the analysis of fibrous feeds. 2. A rapid method for the determination of fiber and lignin, J. AOAC 46 (1963) 829-835. 